ISSN :

Print - $2277-078 \mathrm{X}$

Online - $2315-747 \mathrm{X}$

(c) FUNAAB 2016

\title{
Joumal of

\section{DETERMINANTS OF HERBAL SOAP SMALL ENTERPRISES AND MARKET-LED DEVELOPMENT IN SOUTH WEST, NIGERIA}

\author{
${ }^{*}$ E. 0. A. OLUWALANA, 2 M. F. ADEKUNLE, 2A. M. ADURADOLA \\ 1L. 0., O KOJIE, 10. F ASHAOLU AND 1R. A.SAN USI \\ 1D epartment of Agricultural Economics and Farm Management, \\ 2D epartment of Forestry and Wildlife Management, \\ Federal University of A griculture, A beokuta, O gun State, Nigeria.
}

Comesponding Author: oluwalanaeoa@funaab.edu.ng Tel.: +234

\begin{abstract}
ABST RACT
Research into alternative natural products with health potential such as herbal soap has become very important to curb the disastrous effects of mercury-based soap on healthy living and so enhance women's productive activities of the rural peasantry. The study examines the factors affecting herbal soap small enterprises development and marketing. In identifying the factors affecting the small enterprises, five hundred and two (502) herbal soap processors and marketers were surveyed from South West, Nigeria comprising 65 villages in the sampled 16 Local Government Areas. A close-ended questionnaire was used to gather data for the study. The data collected from herbal soap entrepreneurs was fitted into three regression functional forms. The functional forms were linear, semi-log and double $\log$ functions. The double log function was selected as the lead equation based on the significance of the individual coefficients and their signs, the magnitude of the coefficient of the multiple determinations $\left(R^{2}\right)$ and the magnitude of the standard error (SE) which was 0.80 and F- statistics of 2.35. The $\mathrm{R}^{2}$ of 0.829 indicated that $82.9 \%$ of the variation in the gross profit of herbal soap production $(\mathrm{Y})$ was accounted for by the regressors/explanatory variables. Regression analysis result revealed that, household size and labour were significant at $10 \%$ while extension contact was significant at $5 \%$. It is therefore recommended that, extension contact should be encouraged among the herbal soap processors in other to generate more income, also, awareness should be created for existing and prospective entrepreneurs about business opportunities in Natural resources utilising agricultural-wastes.
\end{abstract}

Keywords: Herbal soap; entrepreneurship, marketing, Natural resources and enterprises.

\section{INTRODUCTION}

Researchers have identified some wastes generated from agro-processing enterprises being utilised by small-scale industry to produce consumer products such as black/ herbal soap (Yusuf and Okoruwa, 1995; Oluyole and Adeogun, 2005). Some of these raw materials from forest and agriculture are classified as non-timber forest products (NTFPs) and agro-processing wastes products. The NTFPs being utilized in Natural Resources Enterprises (NREs) are usually classified into firewood and sawdust (offcuts and dust from sawn timbers); medicinal 
plants (bark; leaves; roots; seeds); ropes, foods and fruits. The agricultural-processing wastes generated by the rural entrepreneurs include cocoa-pod husks (CPHs); Palmkernel Oil (PKO); plantain peels; cassava peels and palm kernel bunches.

Furthermore, forest resources had been confirmed to have close association with rural economic and health activities (Oluyole $\&$ al., 2005). Hence, they can only realize their full potential when their development is integrated into that of agriculture, large forest industries, natural resources development, rural manufacturing and healthbased enterprises (Oluyole $\notin$ al., 2005). For example Herbal soap processing enterprise, which utilizes Non-Timber Forest Products (NTFPs) such as firewood and sawdust ash alongside with agro-processing wastes generated by rural entrepreneurs and some natural products such as pure honey and camwood. These enterprises have some basic characteristics, problems, and economic growth potentials that have to be researched into which resulted into marketoriented economy in East Asian Countries with the phenomenal growth of Hong Kong, Korea, Singapore, and Taiwan Province of China, known as the "Four Tigers" because of their powerful and intimidating economic performance (NASSAB, 2010).

Many entrepreneurs who found and manage SME s lack the appropriate management skills (Lawal \& al., 2000). Hence, lack of adequate capital or sheer ignorance of technological advances, such entrepreneurs purchase obsolete and inefficient equipment thereby setting the stage ab initio, for lower level of productivity, poor product output and market acceptability (Lawal \& al., 2000). The outcome, of course is, closure of some enterprises while many others drastically reduced their scale of operation at the expense of labour. There are many attributes of forest resources that show their importance to national economic and rural development (Oluyole et al., 2005). According to O wualah (1987), this is due to a growing awareness of the potential, social and economic importance of a viable SME sector. The social importance is attributed to their influence in stimulating indigenous entrepreneurship and technology. As they act as seedbed, usually for the populations, they also serve as vehicles for the propagation and diffusion of innovative ideas. It also helps in the transformation of traditional industry thereby creating a smooth transition from the traditional to the modern industrial (O wualah, 1987).

\section{Origin of soap processing enterprises in the world}

When soap was discovered remains a mystery but there were various legends surrounding its beginning. Myth has it that in 1,000 B.C., soap was discovered in Sapon Hill in Rome by a group of women rinsing their clothes at the base of a hill, below a higher elevation where animal sacrifice had taken place (NASSAB, 2010). The women noticed the clothes becoming clean as they were exposed to the soapy clay oozing down the hill and into the water. The same women later discovered this same cleansing substance was formed when animal fat was soaked down through the wood ashes and into the clay soil. (Good Scents Candles, 2006). However, the first evidence of soap making dates back to 2,800 B.C (NASSAB, 2010). According to India Soap Industry (2011), the earliest known evidence of soap use is Babylonian Clay cylinders dating from 2,800 B.C. containing a soap-like substance. On a Babylonian tablet, around 2,200 B.C. were written on formula for soap consisting 
of water, alkali and cassia oil. The early Romans made soaps in the first century A.D . from urine to make a soap-like substance.

\section{Local/ Traditional Soap Production and Marketing}

In West Africa, particularly in Nigeria and G hana, Black soap, herbal or African Black soap has for centuries been produced and marketed (G ood Scents Candies, 2006). For centuries, the traditional methods of processing African Black Soap was mainly from wood ashes, until recently when the soap was being produced from the ashes of natural waste materials such as cocoa pod husks, palm kernel branches, plantain peels and cassava peels (Yusuf and Okoruwa, 1995). Soaps produced from wood ash are well recognized in the traditional setting and served cultures the world over with its efficient bactericidal and dermatological properties. In modern times, the use of soap has become universal due to a better understanding of the role of hygiene and medicinal importance on skin in particular. In India, during the British rule, the Lever Brothers of England introduced modern soaps by importing and marketing them in the country (India) (India Soap Industry, 2011). The first company created was North West Soap Company. The soap manufacturing plant in India was situated in the city of Meerut, in the state of Uttar Pradesh. In 1897, they started marketing cold process soaps. Soap became a necessity for the moneyed class in India by about 1937. At present, Indian per capita consumption of soap is 460 grams per annum, compared to Brazil's 1,100 grams per annum (India soap Industry, 2011).

However, many small herbal soap enterprises are currently unstable, and offer little security or prospect of self-reliance for the rural entrepreneurs (Olubanjo \& al., 2006). These problems needed to be identified and tackled by promoting viable enterprises operated by rural people through effective participatory organisation which can increase the peoples' control over their own economic growth; resources-use efficiency and poverty alleviation strategy. Forests are the world's predominant vegetation and play an important role in rural poverty alleviation; health enhancement, personal hygiene management and environmental sustainability (FAO, 1993).

Yusuf and Okoruwa (1995) reported that, the black soap or herbal soap also known as 'O sedudu' in Yoruba language is being manufactured locally from Palm Kernel Oil (PKO). Also, Cocoa Pod Husks (CPHs) ash or wood ash has been found useful to maintain personal health hygiene and adaptable to the skin and hair of people, thus, the incremental income and employment generation of herbal or black soap making cannot be under-estimated (Egunyobi, 1975). A research carried out by Oluyole and Adeogun (2005) on 'D etermining the Profitability level of Black soap production from cocoa pod husk' revealed that the highest margin average profitability level of black soap production in study area was $36.36 \%$ as confirmed by Yusuf and Okoruwa (1995) study.

In marketing, the aspect of promotion is subject to criticism, because product promotion is supposed to influence demand. In this way producer market power is attained as measured by profits that would not be realized under a free market. Then the argument follows that non-free markets are imperfect and lead to production and consumption of sub optimal amounts of the product (Lawal eal., 2000). 
For Nigeria to move from subsistence level of production to market-oriented economy there is the need to focus research and intervention on Small and Medium Scale Enterprises (SMEs) as carried out by the community, private organisation and Government in East Asian countries otherwise known as A sian Tigers (Lawal \& al., 2000). World Bank, in the study on The East Asian Miracle' in 1993 and 'Adjustment in Africa' in 1994 spelt out the role of industrial policy in economic development, wealth creation, and poverty reduction in East Asian countries (World Bank, 1993). Olayide and Heady (1982) considered that, market orientation was one of the modern powers of growth for the agricultural sector that included forestry sector. Therefore, intervention in terms of research into alternative natural products with health potential such as herbal soap becomes very important to curb the disastrous effects of mercurybased soap on healthy living and so enhance women's productive activities of the rural peasantry. The locally produced herbal soap has been identified by some researchers as natural and organic in nature with high medicinal value; still few people purchase or market it (Olayide and Heady, 1982).

Consequently the study examines factors responsible for low small business participation and market-led development in herbal soap production in South West, Nigeria by looking at;

1. socio-economic problems of the herbal soap processors that hinders production of herbal soap;

2 constraints being faced by the Herbal Soap Entrepreneur (HSE) in penetrating the market and;

3 health and various problems associated with herbal soap process ing activities.

\section{METHODOLOGY}

\section{The Study Area}

The study area is Southwest Geo-political (SWG P) zone of Nigeria. South west area of Nigeria lies between Latitudes $7^{\circ} 01^{\prime}$ and $8^{\circ}$ $14^{\prime}$ and Longitude $2^{\circ} 45^{\prime}$ and $4^{\circ} 15^{\prime}$ and within the tropics along the $\mathrm{G}$ ulf of $\mathrm{G}$ uinea Atlantic O cean on the Western coast of Africa. Kwara and Kogi States bound it on the north and Edo and Delta States on the east. It covers a total land area of $79,795.1 \mathrm{~km} 2$ with a population of over thirty million (NPC, 2006).

\section{Sampling Techniques and Sampling size}

The multi-stage sampling technique was used in selecting the 502 entrepreneurs that participated in the cross-sectional survey adopted for the study. The first stageinvolved stratification of Southwest Nigeria into six states based on political divisionsOgun, Oyo, O sun, Ondo, Ekiti and Lagos States. Each State denotes a stratum. Stratification at the state level made it possible to get enumerators from Agricultural D evelopment Agencies (ADPs). The second stage involved purposive sampling of sixteen (16) LGAs based on pre-test survey information. In the third stage, systematic random sampling procedure was employed to select entrepreneurs/ respondents from the sampled LGAs. This was determined with Probability Proportionate to Size (PPS) based on the population distribution in the strata. There was random selection of the entrepreneurs from the first $\mathrm{K}$ sampling interval by taking the $(i+K)^{\text {th }},(i+2 K)^{\text {th }},(i+3 K)^{\text {th... }}(i+n K)^{\text {th }}$ respondent/ entrepreneur (Adegeye and Dittoh, 1985 ). A kind of purposive selection of entrepreneurs was done at this stage because some entrepreneurs selected by the systematic sampling were non-herbal soap entrepreneurs. These were deliberately replaced with the herbal soap entrepreneurs. 


\section{Source of Data Collection}

The data for this study were collected from both primary and secondary sources. The primary data were collected from respondents through the aid of a structured closeended questionnaire. The secondary data was based on the collection and review of information from literature on internet, published and unpublished journals, files, reports, maps articles, books, and projects on economic potentials of Small and $\mathrm{Me}$ dium Scale Enterprises (SMEs), ForestBased Small Scale Enterprises (FB-SSEs) and Herbal soap production and marketing.

\section{Analytical Tools}

Based on the objectives of the study, the analytical tools employed were inferential statistics such as multiple regression analysis to capture the impact of some selected variables on the herbal soap business from market-led entrepreneurship development. the double-log function used for the regression analysis model is specified as:

$$
\begin{gathered}
\ln Y=b_{0}+b_{1} \ln X_{1}+b_{2} \ln X_{2}+b_{8} \ln X_{3}+\ldots b_{8} \\
\ln _{8}+\dot{\mathrm{e}} \ldots \ldots \ldots \ldots \ldots \ldots \ldots \ldots \text { (1) } \\
\text { where; }
\end{gathered}
$$

$\begin{array}{lll}\mathrm{Y} & = & \begin{array}{l}\text { Income from Herbal Soap } \\ \text { business (\#) }\end{array} \\ \mathrm{X}_{1} & = & \begin{array}{l}\text { Age of Herbal Soap } \\ \text { Processors (Years) }\end{array} \\ \mathrm{X}_{2} & = & \text { Y ears of Experience (Years) } \\ \mathrm{X}_{3} & = & \text { Educational Level (Y ears) } \\ \mathrm{X}_{4} & = & \text { Household Size (Number) } \\ \mathrm{X}_{5} & = & \text { Cost of Ashes (Wood/ } \\ & & \text { Cocoa Pod Husks/ kg) (\#) } \\ \mathrm{X}_{6} & = & \text { Labour } \\ \mathrm{X}_{7} & = & \text { Extension Contact (1 if } \\ & & \text { access to extension contact; } \\ \mathrm{X}_{8} & = & \text { Cif otherwise) } \\ \mathrm{e}_{\mathrm{u}} & = & \text { Credit type } \\ & & \text { error term }\end{array}$

J. Hum. Soc. Sci. \& Crtv. Arts 2016, 11 (1\& 2): 76 - 87

\section{RESULTS AND DISCUSSION OF FINDINGS}

\section{Respondents responses based on Educa- tional level in the Study Area}

The distributions of respondents by educational status show that $84 \%$ had no formal education. Fifty four respondents that is, $10.8 \%$ had incomplete primary school education. This is significant that the custodians of herbal soap knowledge had no formal education indicating that the industry is run by knowledge transfer through field experience (Indigenous knowledge). The low literacy level clearly shows the poor human capital development of the herbal soap entrepreneurs and this could negatively affect the profitability level of the enterprise. It can be deduced that if the processors and marketers had formal education, they would perform better by efficiently utilizing the scare resources available to maximize their profit level and thereby enhance their livelihood status as evidenced by past studies (Oluyole and Adeogun, 2005).

\section{Problems faced by herbal soap producers and marketers}

The Herbal soap producers were interviewed on the problems militating against their performance as shown in Table 1. Figure 2 to 5 revealed that there were twelve problems identified. All the respondents indicated that, they had no access to bank credit. This implied scarcity of funds to expand their businesses. Hence, find it difficult to purchase and use necessary inputs to maximize their profit. Most of the respondents used personal funds and sometimes financial support from friends and relations, cooperatives and sometimes Non-G overnmental O rganizations (NGOs). The respondents could not meet the stringent conditions of collateral and high interest rates charged by the banks. These situations affect the scale of operation 
of herbal soap entrepreneurs.

Lack of extension services which may hinder access to productive information and no value-added technology education had the same score $(100 \%)$. This implied that, there is the need to improve the extension services in the study area by providing the extension officers adequate training and necessary materials for effective performance. Also, included is nonavailability of raw materials (cocoa pod ash) at all times. These constraints make herbal soap enterprise to remain at microscale level. Non-availability of modern equipment accounted for $95 \%$ which affected the productivity of the processors because of drudgery involved in the method of production.

About 90 per-cents of the respondents gave low price of herbal soap as one of the problems encountered by the respondents. This is a multifaceted problem arising from the fact that there are cheaper but not necessarily better industrially massproduced substitutes. Mass production leads to generally low cost of production per unit, and hence more profit. At the current level of indigenous technology, herbal soap cannot be mass produced. There is generally no scientific and industrial advertisement of herbal soap in the study area, indeed in Nigeria. Advertisement on radio, television and giant billboards are veritable tools of marketing employed by the producers of industrially mass-produced soaps. Till today, Castle soap is recognized all over the world in spite of other soaps that have come to be produced. Even handcrafted soaps are marketed by industrial nations using the power of internet and viral marketing. Herbal soap in Nigeria is not branded. The "Alata Soap" that Ghana is today celebrating is said to be an export product to Ghana from Awe community in Oyo State in Nigeria. Because of the settler nature of this group of Nigerians, they took the soap to Ghana and having settled there in Ghana, they continued with the herbal soap production. Today, after many decades there "Alata" soap is now regarded as a Ghanaian product. "Alata" (meaning "owner of pepper") is strictly a Yoruba word in Nigeria (NASSAB, 2010).
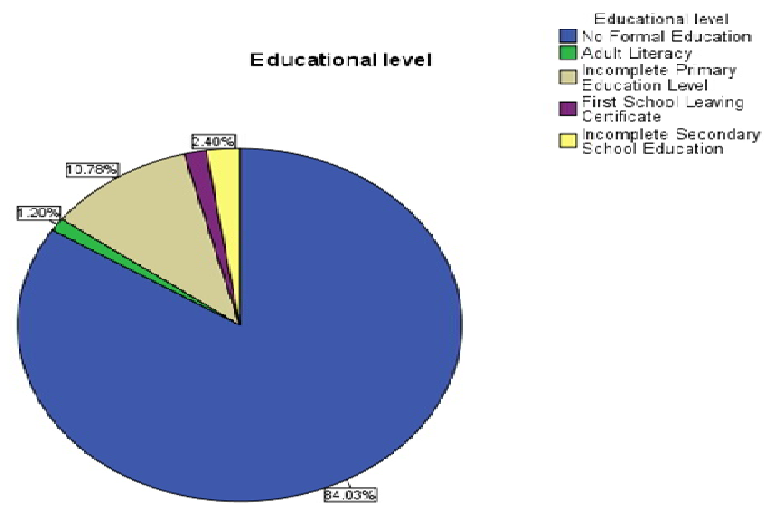

Figure 1: Distribution of Respondents by Educational level per State in the Study Area 
Table 1: Distribution of Herbal Soap Processors by Problems Encountered

\begin{tabular}{|c|c|c|}
\hline Problems & Frequency* & Percentage \\
\hline $\begin{array}{l}\text { Inaccessibility to bank } \\
\text { credit facilities (Lack of } \\
\text { funds) }\end{array}$ & 502 & 100 \\
\hline $\begin{array}{l}\text { Non availability of raw ma- } \\
\text { terials (e.g. cocoa pod ash) } \\
\text { at all times (High cost of } \\
\text { raw material) }\end{array}$ & 502 & 100 \\
\hline Lack of extension services & 502 & 100 \\
\hline $\begin{array}{l}\text { Low awareness of eco- } \\
\text { nomic potentials of herbal } \\
\text { soap }\end{array}$ & 502 & 100 \\
\hline $\begin{array}{l}\text { Micro or small scale opera- } \\
\text { tion }\end{array}$ & 502 & 100 \\
\hline $\begin{array}{l}\text { Poor value- added technol- } \\
\text { ogy education }\end{array}$ & 502 & 100 \\
\hline $\begin{array}{l}\text { Non availability of modern } \\
\text { equipment }\end{array}$ & 476 & 95 \\
\hline $\begin{array}{l}\text { Low price of herbal soap in } \\
\text { the market hence low profit }\end{array}$ & 450 & 91 \\
\hline Poor health issue & 427 & 85 \\
\hline Poor road network & 302 & 60 \\
\hline Price of other substitutes & 250 & 50 \\
\hline Poor level of education & 250 & 50 \\
\hline
\end{tabular}

Source: Computed from field survey data, 2015; * Multiple Responses

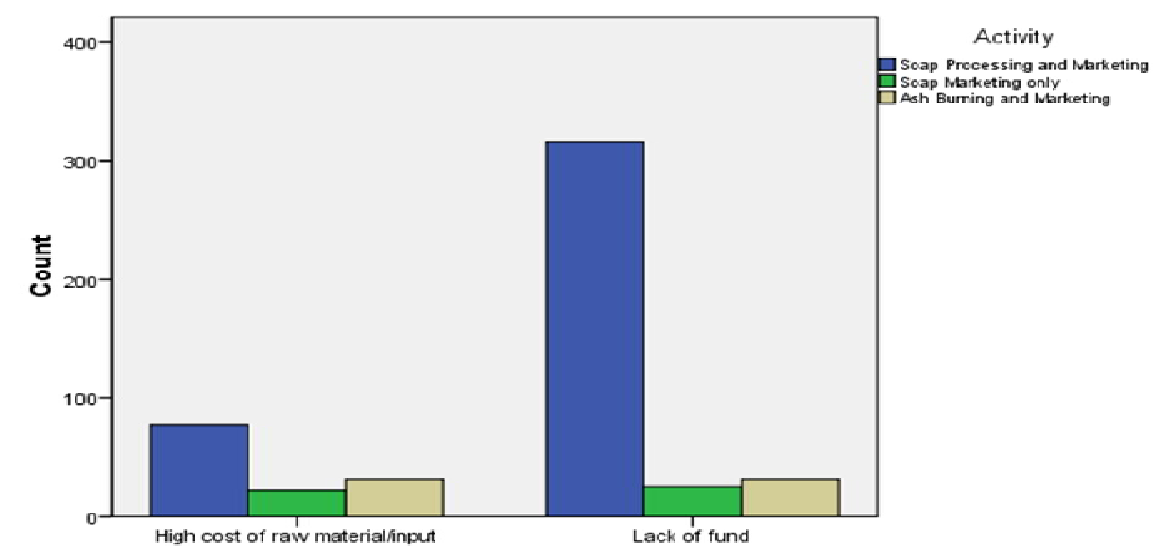

Figure 2: Distribution of Problems of High Cost of Raw Materials and Lack of Funds in relations to herbal soap processing activities

J. Hum. Soc. Sci. \& Crtv. Arts 2016, 11 (1 \& 2): 76 - 87 


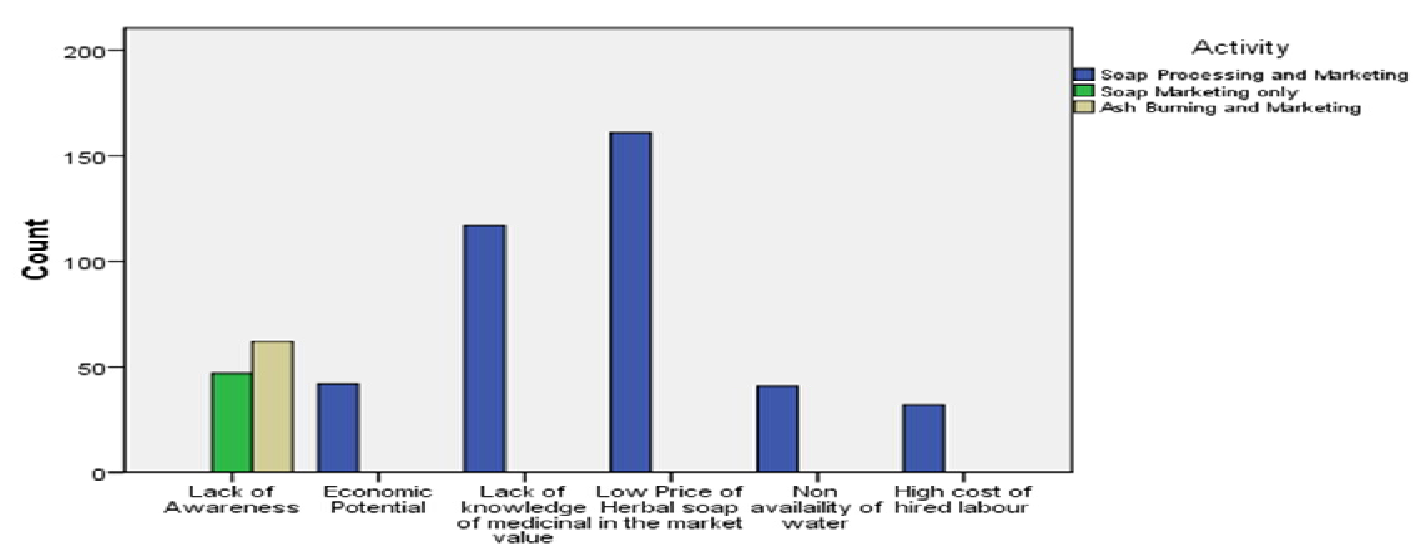

Figure 3: Distribution of various problems in relations to herbal soap processing activities

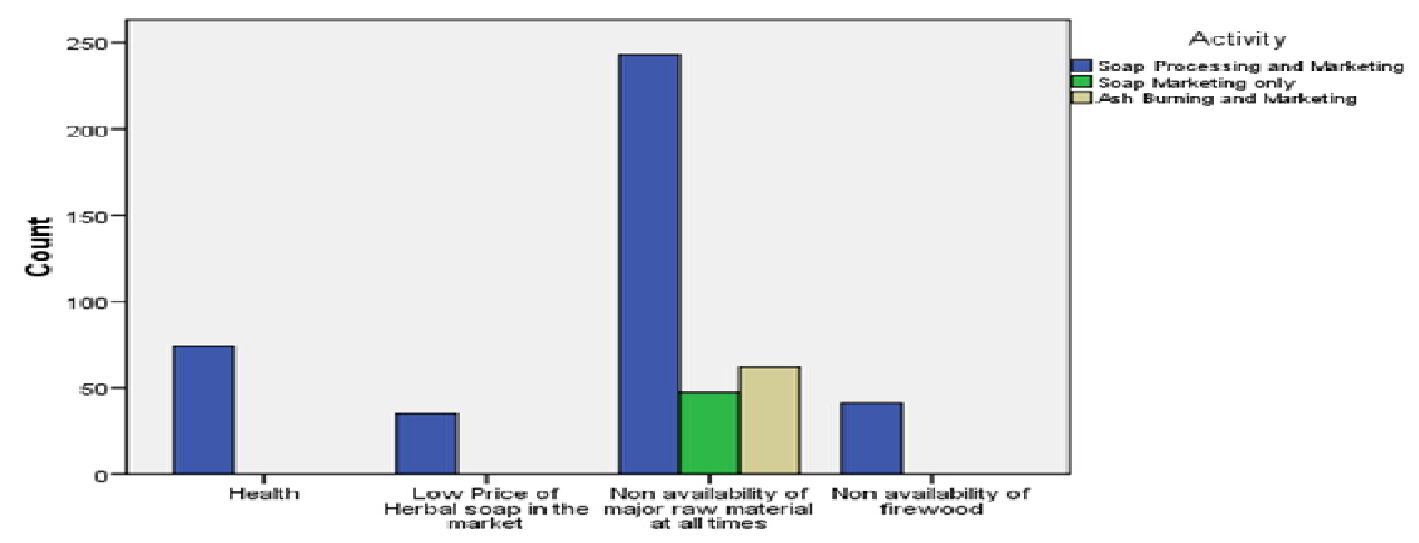

Figure 4: Distribution by Health Problems and others problems associated with herbal soap processing activities

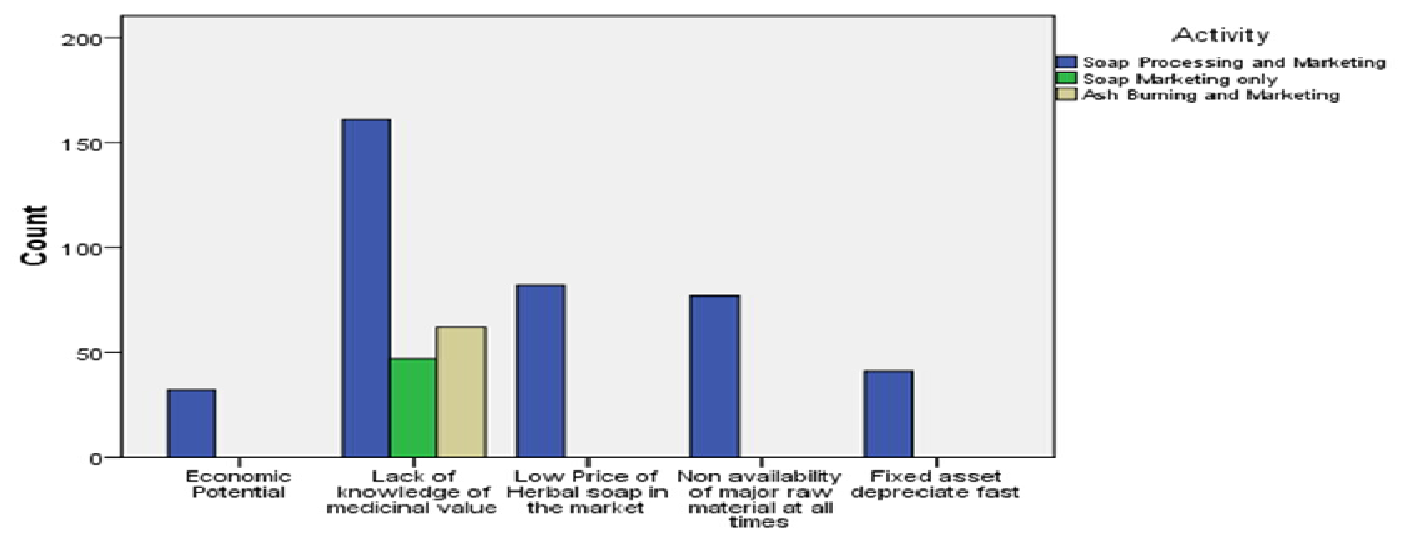

Figure 5: Distribution of Economic Potential Problems and others in relations to herbal soap processing activities 
Also, included are non availability of raw materials (cocoa pod ash) at all times and low awareness about economic potentials of herbal soap. As a result of these constraints made Herbal soap enterprise to remain in Micro scale level. Also they apply indigenous knowledge without modern technology and skills available through extension services. Non-availability of modern equipment accounted for 95\% which affect the productivity of the processors because of drudgery involved in the method of production. $90.9 \%$ represented low price of Herbal soap. This is because of lack of awareness for the medicinal potential of soap to human body. The multiple effect of this is reduction in revenue and profitability generated by the respondents. Poor health issue accounted for $85 \%$ of the complaint meaning that the work is hazardous to the health of entrepreneurs.

Poor road network accounted for $60 \%$ of problems encountered; the respondents stated that, it is always very difficult to get out from the farm the cocoa pod husk or cocoa pod ash. Therefore the need for all the cocoa producing states to invest into modern equipment to dry ash and package the ash during the time of glut, in order to have the product throughout the year. This will also serve as natural waste management on the farms where the hips of the empty pods has been constituting nuisance to the health of cocoa trees as well as human be- ing. Lastly poor level of education and price of other substitutes accounted for $50 \%$ of the complaints.

The data collected from herbal soap entrepreneurs was fitted into three regression functional forms. The functional forms were linear, semi-log and double log functions. The double log function was selected as the lead equation based on the significance of the individual coefficients and their signs, the magnitude of the coefficient of the multiple determinations $\left(R^{2}\right)$ and the magnitude of the standard error (SE) which was 0.80 and F- statistics of 2.35. Table 2 and Table 3 revealed the results for the estimation of factors that determine production of herbal soap in the study area. The selected lead equation which was estimated using the ordinary least square regression method in explicit functional form is as stated below:

$$
\begin{aligned}
& \log Y=\log a+a_{1} \log X_{1}+a_{2} \log X_{2}+ \\
& a_{3} \log X_{3}+\ldots a_{7} \log X_{7}+a_{8} \log X_{8-\cdots \ldots-\ldots-. .-}(2) \\
& =9.955-.870 \log X_{1}+.404 \log X_{2} \\
& +.053 \log X_{3}-.217 \log X_{4}+2.15 \log X_{5}+ \\
& 0.142 \log X_{6} \\
& \quad(-3.622) \quad(+3.632) \quad(+3.241) \\
& (-1.451) \quad(5.826) \quad(1.672) \\
& +0.557 \log X_{7}+0.693 \log X_{8-\cdots} \\
& (5.465) \quad(6.300)
\end{aligned}
$$




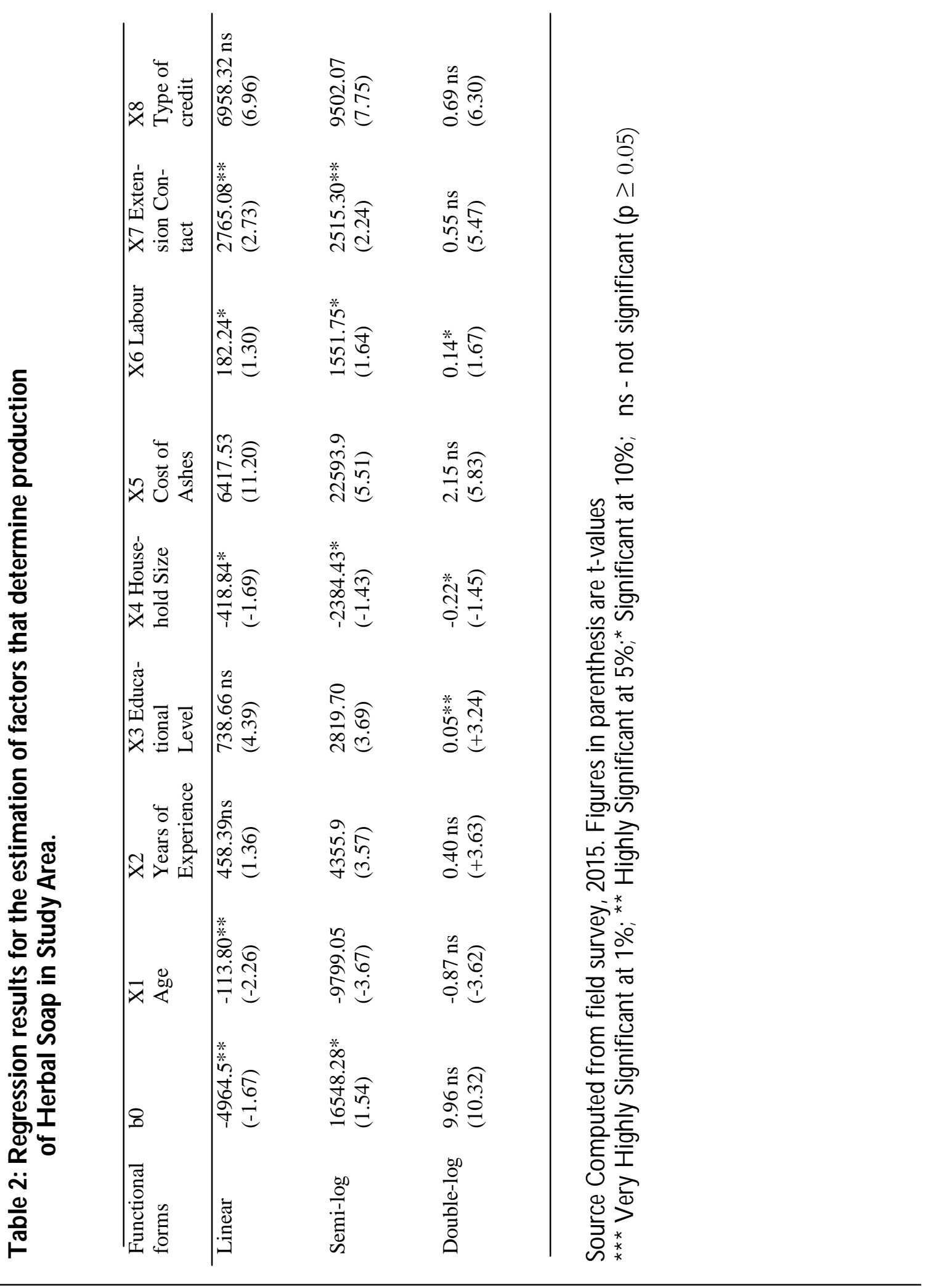

J. Hum. Soc. Sci. \& Crtv. Arts 2016, 11 (1\& 2): 76 - 87 


\section{CONCLUSIONS}

The study revealed that 164 respondents (84\%) had no formal education. Twentyone $(10.8 \%)$ had incomplete primary school education. Low literacy level clearly shows the poor human capital development of the herbal soap entrepreneurs and this could negatively affect the profitability level of the enterprise. Hence, if the processors and marketers had formal education, they will perform better by efficiently utilizing the scare resources available to maximize their profit level and thereby reduce their poverty level.

The study further revealed that, the Herbal Soap Entrepreneurs/producers (HSE/P) most commonly cited finance as the principal problem they encounter in maintaining their competitive position, with high cost of raw material are often being mentioned as the second most important. Others are small and insecure markets, raw material shortages, shortage of finance, nonavailabilities of appropriate technology in the form of suitable tools and equipment.

Based on the revealed problems facing $\mathrm{HSE} / \mathrm{P}$, the following recommendations were made;

1. The stakeholders such as Universities, Researchers, Governments, Non- Governmental Organizations (NGOs), Community-based groups and individuals' should utilize opportunities and profitability existing in the Indigenous knowledge (IK) of rural entrepreneurs especially in herbal soap production and marketing;

2.There is the need to unlock the credit market with initiative interventions by stakeholders through develop- ing internal capacity that will de-risk lending to the youth and women without tangible collateral for the credit assistance;

3. Awareness should be created for existing and prospective entrepreneurs about business opportunities in Forest-based enterprises utilising agricultural-wastes generated during commercial processing such as Cocoa pod husks and cassava peels for Herbal soap making and;

4. Assistance should be given to entrepreneurs to acquire the basic knowledge/ principles of business, preparing prospective entrepreneurs for effective business entry and practical demonstration of certain aspect of the business (such as Network analysis; Sensitivity analysis; Technical allocation and Economic efficiencies of the enterprise.

\section{REFERENCES}

Adegeye, A. J. and Dittoh, J. S. (1985). Essentials of Agricultural Economics.

Nigeria: Impact Publishers, Ibadan.

FA0, 1993. Assessing Forestry Project Impacts: Issues and Strategies. FAO Forestry Paper 114. Rome 72pp.

Good Scents Candies, 2006. History and use of Soap: Soap in Ancient Times. http:/ / www.goodscentsscandies.ussoaphistory.php. Indian Soap Industry. http/ / :www.indianmirrow.com/ Indianindustries/ soap.html.assessed

2/ 17/ 2011.

Lawal, A.A., Kio, J.S., Sulaimon, A. A. 
and Adebayo, 0.I. (2000). Entrepreneur- CARE NIG. LTD \& GREEN HERBS AFshipD evelopment in Small Scale Business. RICANA. Held in MPB 02, University of Nigeria, Labson Resource Nigeria Ltd. Agriculture, Abeokuta 12th-13th D ec, 2006 309pp

NASSAB, (2010). Shea Butter and Black

Oluyole, K.A. and Adeogun, S.O. (2005). Soap Co., Ghana. A Brief History of Black Soap Alata Samina. or AnagoSamina. http:/ / www.sheabuttter.co/ nasaebbnew/ factssheablack.htm.assessed2/ 18/ 2011.

D etermining the Profitability level of Black Soap production from Cocoa Pod Husk in Lagelu Local Government Area of Oyo state. Journal of Agriculture, Forestry and Social Sciences (JOAFSS),Vol 3No 1.

National Population Commission. 2006. www.population.gov.ng/ index.php/ .../ artide .../ 95-2006-censusprionity-tablesvol-1

Owualah, S. (1987), "Nigeria's economy and its career promise for the mature employee", The G uardian Lagos, Newspaper

Olayide. S.O., Heady, E.0. (1982). Introduction to agricultural production economics. University of Ibadan press Nigeria. Chapters 2,3 and 7.

World Bank, 1993. The East A sian Miracle, New York: Oxford University Press.

Yusuf S.A. and Okonuwa V.0. (1995). Transforming Wastes into Money: The case Olubanjo Adebola and Oluwalana ofBlack soap making using Cocoa Pod E.0.A 2006. Record keeping in Herbal Husks. In: Cocoa Revolution in Nigeria. SMEs. Paper presented at the Training Proceedings of a National Seminar on RevoCourse on Herbs and Health Organized by lutionizing Nigeria's Cocoa Industry. UniverD ept. of Forestry and Wildlife Management sity of Ibadan. Nigeria. 101-112 UNAAB, In Collaboration with ROHI-

(Manuscipt recived: 17thFednuary, 2017; accepted 23rdJune, 2017 